\title{
Effects of Solanum nigrum, Crassocephalum crepidioides and Bidens pilosa straws on the nutrients content of soil and grape seedlings under cadmium stress
}

\author{
Kewen Huang, Xinyu Gao, Ling Xiao, Junjiang Shu, Qinyuan Li and Ming'an Liao* \\ College of Horticulture, Sichuan Agricultural University, Chengdu, Sichuan, 611130, China
}

\begin{abstract}
In order to improve the nutrients absorption of grape seedlings under cadmium (Cd) stress, the effects of Solanum nigrum, Crassocephalum crepidioides and Bidens pilosa straws on the nutrients content of soil and grape seedlings under Cd stress were studied by pot experiment. According to the results, the activity of soil phosphatase, soil catalase and soil sucrose by soil application of straws observed higher than CK to varying degrees. And soil application of straws increased the contents of soil alkaline nitrogen and available phosphorus in different degrees, while soil application of $B$. pilos $a$ straws decreased the content of soil available potassium. In addition, the soil application of straws had a certain promoting effect on the total nitrogen content, total phosphorus content and total potassium content of grape seedlings compared with the CK. Among all treatments, C. crepidioides straws maximized the nutrients content in the shoots of grape seedlings, which could provide reference for grape cultivation in Cd-contaminated areas.
\end{abstract}

\section{Introduction}

Cadmium (Cd) is known for its superior biological toxicity that not only damages the ecological environment but also has a significant negative impact on the production of economic crops. In order to alleviate the toxic effects of $\mathrm{Cd}$ on plants, study has attempted to reduce the $\mathrm{Cd}$ absorption of plants by intercropping with hyperaccumulators [1]. However, due to the low biomass, strong regionality and long repair time of hyperaccumulators, it is difficult to widely promote the application of intercropping with hyperaccumulators. In agricultural production, straw returning is a way to effectively reuse straw, which is widely used because of its good biological effects on farmland. Additionally, report has shown that the use of hyperaccumulators straws returned to the field could affect the form and availability of $\mathrm{Cd}$ in soil, and provides more reference for regulating the absorption of $\mathrm{Cd}$ by plants [2]. Grape has a long history of cultivation, with high nutritional value and medical care function, and is well received by consumers. However, report has shown that a large number of vineyards have been contaminated with $\mathrm{Cd}$ to varying degrees, which is not conducive to the cultivation and production of grapes [3]. Solanum nigrum, Crassocephalum crepidioides and Bidens pilosa are all hyperaccumulators, even though they can reduce the $\mathrm{Cd}$ content of other plants by intercropping, they may compete with economic crops during growth [4-6]. Related study has implied that under Cd stress, the effects of living hyperaccumulator and its straw on the accumulation of $\mathrm{Cd}$ in other plants are significantly different [7]. Thus, we studied the effects of soil application of $S$. nigrum, C. crepidioides and $B$. pilosa straws on the nutrients content of grape seedlings and soil to promote the absorption of nutrients by grape seedlings under Cd stress.

\section{$2 \quad$ Materials and methods}

\subsection{Materials}

In March 2018, the Solanum nigrum, Crassocephalum crepidioides and Bidens pilosa were collected from farmland around the Chengdu Campus of Sichuan Agricultural University. After washing with deionized water, plant samples were dried at $110{ }^{\circ} \mathrm{C}$ for $15 \mathrm{~min}$, dried at $80^{\circ} \mathrm{C}$ to a constant weight, cut to a length of less than $1 \mathrm{~cm}$ and stored. The test grape seedlings were twoyear-old 'Jiufeng', and were purchased at the seedling base of Longquanyi District, Chengdu City, Sichuan Province in May 2018. The tested soil was taken from the farmland around the Chengdu Campus of Sichuan Agricultural University. The basic physical and chemical properties were as follows: soil $\mathrm{pH}$ was 7.09 , total nitrogen content was $1.50 \mathrm{~g} / \mathrm{kg}$, total phosphorus content was $0.76 \mathrm{~g} / \mathrm{kg}$, total potassium content was $18.02 \mathrm{~g} / \mathrm{kg}$, alkali nitrogen content was $94.82 \mathrm{mg} / \mathrm{kg}$, available phosphorus content was $6.30 \mathrm{mg} / \mathrm{kg}$, available potassium content was $149.59 \mathrm{mg} / \mathrm{kg}$ and the content of total $\mathrm{Cd}$ was $0.02 \mathrm{mg} / \mathrm{kg}$.

\subsection{Experimental design}

*Corresponding author's e-mail: lman@sicau.edu.cn 
In April 2018, the soil was air-dried, crushed and sieved, and then weighed $3.0 \mathrm{~kg}$ into a plastic pot with $15 \mathrm{~cm}$ height and $18 \mathrm{~cm}$ diameter. Then $\mathrm{CdCl}_{2} 2.5 \mathrm{H}_{2} \mathrm{O}$ solution was added to make the $\mathrm{Cd}$ concentration reach $5 \mathrm{mg} / \mathrm{kg}$, and the mixture was naturally placed for 4 weeks. In May 2018, the treated straws were mixed with the Cd treated soil, and $2 \mathrm{~g}$ of straws per kilogram of soil was applied, and then the water was kept moist and balanced for 2 weeks. Grape seedlings with consistent growth were selected and planted in pots, 3 plants per pot, and each treatment was repeated 3 times. There are four treatments in this experiment: no straws (CK), S. nigrum straws, $C$. crepidioides straws and B. pilosa straws. The management of the grapes seedlings was carried out according to the standard pot management method. The positions were randomly changed from time to time, and soil moisture content was about $80 \%$ of the field water holding capacity. After 60 days, the whole grape seedlings were harvested and the rhizosphere soil was collected separately. The roots, stems and leaves of grape seedlings were washed with deionized water for 3 times, dried to balance weight. Then, the total nitrogen, total phosphorus, total potassium contents in different parts of grape seedlings and the available potassium, alkaline nitrogen, available phosphorus contents in soil were determined by the method of Bao [8]. The activity of soil sucrose, soil catalase and soil phosphatase were determined by the method of Guan [9].

\subsection{Statistical analyses}

Statistical analysis was carried out by using SPSS 18.0 statistical software. The data were analyzed by one-way ANOVA, with the least significant difference at the 5\% confidence level.

\section{$3 \quad$ Results and discussion}

\subsection{Effects of S. nigrum, C. crepidioides and B. pilosa straws on the activity of soil enzyme under cadmium stress}

It can be seen from Table 1 that soil application of straws increased soil enzyme activity to varying degrees. Regarding as soil phosphatase, the order of soil phosphatase activity was: $B$. pilosa straws $>C$. crepidioides straws $>S$. nigrum straws $>\mathrm{CK}$. Additionally, both the orders of soil catalase activity and soil sucrase activity were: $C$. crepidioides straws $>B$. pilosa straws $>S$. nigrum straws $>\mathrm{CK}$. And soil application of $C$. crepidioides straws and B. pilosa straws increased the soil sucrase activity to a significant level, which was $76.71 \%$ and $36.09 \%$ higher than the control, respectively.

Table 1. Effects of $S$. nigrum, C. crepidioides and B. pilosa straws on activity of soil enzyme under cadmium stress

\begin{tabular}{cccc}
\hline Treatments & $\begin{array}{c}\text { Soil catalase activity } \\
(\mathrm{mL} / \mathrm{g})\end{array}$ & $\begin{array}{c}\text { Soil phosphatase activity } \\
(\mathrm{mg} / \mathrm{g})\end{array}$ & $\begin{array}{c}\text { Soil sucrase activity } \\
(\mathrm{mg} / \mathrm{g})\end{array}$ \\
\hline CK & $1.420 \pm 0.147 \mathrm{a}$ & $120.902 \pm 16.480 \mathrm{a}$ & $7.399 \pm 0.804 \mathrm{c}$ \\
S. nigrum straws & $1.541 \pm 0.212 \mathrm{a}$ & $122.679 \pm 17.987 \mathrm{a}$ & $7.863 \pm 0.539 \mathrm{c}$ \\
C. crepidioides straws & $2.019 \pm 0.286 \mathrm{a}$ & $134.099 \pm 12.047 \mathrm{a}$ & $13.075 \pm 0.901 \mathrm{a}$ \\
B. pilosa straws & $1.554 \pm 0.193 \mathrm{a}$ & $143.272 \pm 19.703 \mathrm{a}$ & $10.069 \pm 0.846 \mathrm{~b}$ \\
\hline
\end{tabular}

Values are means \pm standard errors of three replicate pots. Different lowercase letters within a column indicate significant differences based on a one-way analysis of variance in SPSS 20.0, followed by the least significant difference test $(p<0.05)$.

\subsection{Effects of S. nigrum, C. crepidioides and B. pilosa straws on the nutrients content of soil under cadmium stress}

It can be seen from Table 2 that there are differences in soil available potassium, available phosphorus and alkaline nitrogen contents between different straws. For soil available potassium and soil alkaline nitrogen, there were no significant difference in contents of available potassium and alkaline nitrogen between soil application of straws and CK. The order of soil available potassium content was: $C$. crepidioides straws $>S$. nigrum straws $>$ $\mathrm{CK}>B$. pilosa straws, and the order of soil alkaline nitrogen content was: $C$. crepidioides straws $>S$. nigrum straws $>$ B. pilosa straws $>$ CK. Regarding as soil available phosphorus, the order of soil available phosphorus content was: $B$. pilosa straws $>C$. crepidioides straws $>S$. nigrum straws $>$ CK. Moreover, soil application of $B$. pilosa and $C$. crepidioides straws significantly increased the content of soil available phosphorus by $43.47 \%$ and $34.85 \%$ compared to the CK, respectively.

Table 2. Effects of S. nigrum, C. crepidioides and B. pilosa straws on the nutrients content of soil under cadmium stress

\begin{tabular}{cccc}
\hline Treatments & $\begin{array}{c}\text { Soil available potassium content } \\
(\mathrm{mg} / \mathrm{kg})\end{array}$ & $\begin{array}{c}\text { Soil available phosphorus content } \\
(\mathrm{mg} / \mathrm{kg})\end{array}$ & $\begin{array}{c}\text { Soil alkaline nitrogen content } \\
(\mathrm{mg} / \mathrm{kg})\end{array}$ \\
\hline CK & $47.441 \pm 0.25 \mathrm{ab}$ & $11.527 \pm 0.71 \mathrm{c}$ & $118.207 \pm 7.3 \mathrm{a}$ \\
S. nigrum straws & $48.127 \pm 1.31 \mathrm{ab}$ & $13.516 \pm 0.71 \mathrm{~b}$ & $123.411 \pm 8.2 \mathrm{a}$ \\
C. crepidioides straws & $49.245 \pm 0.92 \mathrm{a}$ & $15.544 \pm 0.71 \mathrm{a}$ & $124.875 \pm 2.7 \mathrm{a}$ \\
B. pilos straws & $46.723 \pm 0.67 \mathrm{~b}$ & $16.538 \pm 0.71 \mathrm{a}$ & $121.697 \pm 4.6 \mathrm{a}$ \\
\hline
\end{tabular}

Values are means \pm standard errors of three replicate pots. Different lowercase letters within a column indicate significant differences based on a one-way analysis of variance in SPSS 20.0, followed by the least significant difference test $(p<0.05)$. 


\subsection{Effects of S. nigrum, C. crepidioides and B. pilosa straws on the total nitrogen content of soil under cadmium stress}

As can be seen from Table 3 that compared with the CK, the soil application of hyperaccumulators straws significantly increased the total nitrogen content of the roots, stems and leaves of the grape seedlings under $\mathrm{Cd}$ stress. And the order of total nitrogen content in grape seedlings shoots was: $C$. crepidioides straws $>B$. pilosa straws $>S$. nigrum straws $>$ CK. In addition, soil application of $C$. crepidioides straws made the total nitrogen content of the stems and shoots of the grape seedlings reach the maximum, which was74.38\% and $84.27 \%$ higher than the $\mathrm{CK}$, respectively.

\subsection{Effects of S. nigrum, C. crepidioides and B. pilosa straws on the total phosphorus content of soil under cadmium stress}

Table 4 shows that the soil application of hyperaccumulators straws significantly increased the total phosphorus content in different parts of grape seedlings. Interestingly, the all orders of total phosphorus content in roots, stems, leaves and shoots of grape seedlings were: $C$. crepidioides straws $>B$. pilosa straws $>S$. nigrum straws $>$ CK. Compared with the CK, soil application of $C$. crepidioides straws increased the total phosphorus content of grape seedlings roots, stems, leaves and shoots by $12.73 \%, 30.44 \%, 5.49 \%$ and $10.70 \%$, respectively.

Table 3. Effects of S. nigrum, C. crepidioides and B. pilosa straws on the total nitrogen content of soil under cadmium stress

\begin{tabular}{ccccc}
\hline Treatments & $\begin{array}{c}\text { Roots } \\
(\mathrm{g} / \mathrm{kg})\end{array}$ & $\begin{array}{c}\text { Stems } \\
(\mathrm{g} / \mathrm{kg})\end{array}$ & $\begin{array}{c}\text { leaves } \\
(\mathrm{g} / \mathrm{kg})\end{array}$ & $\begin{array}{c}\text { Shoots } \\
(\mathrm{g} / \mathrm{kg})\end{array}$ \\
\hline $\mathrm{CK}$ & $0.513 \pm 0.006 \mathrm{c}$ & $0.160 \pm 0.012 \mathrm{c}$ & $0.805 \pm 0.006 \mathrm{c}$ & $0.623 \pm 0.113 \mathrm{~b}$ \\
S. nigrum straws & $0.553 \pm 0.008 \mathrm{~b}$ & $0.235 \pm 0.005 \mathrm{~b}$ & $1.085 \pm 0.001 \mathrm{a}$ & $0.839 \pm 0.107 \mathrm{ab}$ \\
C. crepidioides straws & $0.674 \pm 0.013 \mathrm{a}$ & $0.279 \pm 0.002 \mathrm{a}$ & $1.077 \pm 0.007 \mathrm{a}$ & $1.148 \pm 0.106 \mathrm{a}$ \\
B. pilosa straws & $0.688 \pm 0.017 \mathrm{a}$ & $0.247 \pm 0.003 \mathrm{~b}$ & $0.851 \pm 0.012 \mathrm{~b}$ & $1.127 \pm 0.262 \mathrm{a}$ \\
\hline
\end{tabular}

Values are means \pm standard errors of three replicate pots. Different lowercase letters within a column indicate significant differences based on a one-way analysis of variance in SPSS 20.0, followed by the least significant difference test $(p<0.05)$.

Table 4. Effects of S. nigrum, C. crepidioides and B. pilosa straws on the total phosphorus content of soil under cadmium stress

\begin{tabular}{ccccc}
\hline Treatments & $\begin{array}{c}\text { Roots } \\
(\mathrm{g} / \mathrm{kg})\end{array}$ & $\begin{array}{c}\text { Stems } \\
(\mathrm{g} / \mathrm{kg})\end{array}$ & $\begin{array}{c}\text { leaves } \\
(\mathrm{g} / \mathrm{kg})\end{array}$ & $\begin{array}{c}\text { Shoots } \\
(\mathrm{g} / \mathrm{kg})\end{array}$ \\
\hline $\mathrm{CK}$ & $0.652 \pm 0.003 \mathrm{c}$ & $0.611 \pm 0.613 \mathrm{c}$ & $0.656 \pm 0.007 \mathrm{~b}$ & $0.645 \pm 0.007 \mathrm{c}$ \\
S. nigrum straws & $0.670 \pm 0.007 \mathrm{~b}$ & $0.673 \pm 0.669 \mathrm{~b}$ & $0.680 \pm 0.010 \mathrm{a}$ & $0.677 \pm 0.009 \mathrm{~b}$ \\
C. crepidioides straws & $0.735 \pm 0.001 \mathrm{a}$ & $0.797 \pm 0.794 \mathrm{a}$ & $0.692 \pm 0.004 \mathrm{a}$ & $0.714 \pm 0.002 \mathrm{a}$ \\
B. pilosa straws & $0.678 \pm 0.010 \mathrm{~b}$ & $0.697 \pm 0.689 \mathrm{~b}$ & $0.686 \pm 0.005 \mathrm{a}$ & $0.686 \pm 0.007 \mathrm{~b}$ \\
\hline
\end{tabular}

Values are means \pm standard errors of three replicate pots. Different lowercase letters within a column indicate significant differences based on a one-way analysis of variance in SPSS 20.0, followed by the least significant difference test $(p<0.05)$.

\subsection{Effects of S. nigrum, C. crepidioides and B. pilosa straws on the total potassium content of soil under cadmium stress}

In the table 5, the soil application of hyperaccumulators straws had no significant effect on the total potassium content in the leaves and shoots of grape seedlings, but significantly increased the total potassium content of roots and stems. The order of total potassium content in grape seedlings roots was: $B$. pilosa straws $>C$. crepidioides straws $>S$. nigrum straws $>\mathrm{CK}$. And the order of total potassium content in grape seedlings stems was: C. crepidioides straws $>B$. pilosa straws $>S$. nigrum straws $>\mathrm{CK}$.

Table 5. Effects of S. nigrum, C. crepidioides and B. pilosa straws on the total potassium content of soil under cadmium stress

\begin{tabular}{ccccc}
\hline Treatments & $\begin{array}{c}\text { Roots } \\
(\mathrm{g} / \mathrm{kg})\end{array}$ & $\begin{array}{c}\text { Stems } \\
(\mathrm{g} / \mathrm{kg})\end{array}$ & $\begin{array}{c}\text { leaves } \\
(\mathrm{g} / \mathrm{kg})\end{array}$ & $\begin{array}{c}\text { Shoots } \\
(\mathrm{g} / \mathrm{kg})\end{array}$ \\
\hline CK & $1.449 \pm 0.015 \mathrm{~b}$ & $1.329 \pm 0.019 \mathrm{c}$ & $1.227 \pm 0.031 \mathrm{a}$ & $1.232 \pm 0.056 \mathrm{a}$ \\
S. nigrum straws & $1.691 \pm 0.008 \mathrm{a}$ & $1.454 \pm 0.048 \mathrm{~b}$ & $1.249 \pm 0.017 \mathrm{a}$ & $1.313 \pm 0.046 \mathrm{a}$ \\
C. crepidioides straws & $1.703 \pm 0.010 \mathrm{a}$ & $1.577 \pm 0.008 \mathrm{a}$ & $1.308 \pm 0.013 \mathrm{a}$ & $1.358 \pm 0.056 \mathrm{a}$ \\
B. pilosa straws & $1.710 \pm 0.008 \mathrm{a}$ & $1.494 \pm 0.013 \mathrm{~b}$ & $1.295 \pm 0.044 \mathrm{a}$ & $1.316 \pm 0.097 \mathrm{a}$ \\
\hline
\end{tabular}

Values are means \pm standard errors of three replicate pots. Different lowercase letters within a column indicate significant differences based on a one-way analysis of variance in SPSS 20.0, followed by the least significant difference test $(p<0.05)$. 


\section{Conclusions}

Soil application of Solanum nigrum, Crassocephalum crepidioides and Bidens pilosa straws had different effects on the nutrients content of soil and grape seedlings under Cd stress. According to the experiment, the activity of soil phosphatase, soil catalase and soil sucrose by soil application of straws observed higher than CK to varying degrees. In addition, there were no significant difference in contents of available potassium and alkaline nitrogen between soil application of straws and CK, while the content of soil available phosphorus content was significantly higher than that of CK. Furthermore, soil application of hyperaccumulators straws increased the total nitrogen content, total phosphorus content and total potassium content in all parts of grape seedlings. Among all treatments, soil application of $C$. crepidioides made the total nitrogen, total phosphorus and total potassium content of the shoots of grape seedlings reach the maximum, which had the best effect on the nutrients content of grape seedlings.

\section{References}

1. Sun, G.C., Li, H.Y., Liao, M.A., Lin, L.J., Tang, Y., Wang, Z.H. (2019) Effects of intercropping with Caryophyllaceae accumulator plants on cadmium accumulation of Cyphomandra betacea seedlings. Hunan. Agro. Sci., 2: 13-17.

2. Jia, L., Zhu, J.Y., Su, D.C. (2010) Effects of crop straw return on soil cadmium contaminated soil. J. Agro. Environ. Sci., 29: 1992-1998.

3. Yang, Y., Ying, C.F., Tang, J.L., Zhang, P., Xu, H., Cheng, X.M., Tong, X.C. (2017) Analysis and pollution assessment of heavy metal contamination in grape orchard soils in Changsha and Zhuzhou. Hunan. Agro. Sci., 8: 41-44.

4. Sun, Y.B., Zhou, Q.X., Diao, C.Y. (2008) Effects of cadmium and arsenic on growth and metal accumulation of Cd-hyperaccumulator Solanum nigrum L.. Bioresource. Technol., 99: 1103-1110.

5. Yamato, M., Yoshida, S., Iwase, K. (2008) Cadmium accumulation in Crassocephalum crepidioides (Benth.) S. Moore (Compositae) in heavy-metal polluted soils and Cd-added conditions in hydroponic and pot cultures. Soil. Sci. Plant. Nutr., 54: 738-743.

6. Sun, Y.B., Zhou, Q.X., Wang, L., Liu, W.T. (2009) Cadmium tolerance and accumulation characteristics of Bidens pilosa L. as a potential Cdhyperaccumulator. J. Hazard. Mater., 161: 808-814.

7. Huang, K.W., Lin, L.J., Chen, F.B., Liao, M.A., Wang, J., Tang, Y., Lai, Y.S., Liang, D., Xia, H., Wang, X., Ren, W. Effects of live Myriophyllum aquaticum and its straw on cadmium accumulation in Nasturtium officinale. Environ. Sci. Pollut. R., 24: 22503-22509.

8. Bao, S.D. (2000) Agrochemical Soil analysis. China Agriculture Press, Beijing.
9. Guan, S.Y. (1986) Soil enzymes and its research methods. China Agriculture Press, Beijing. 